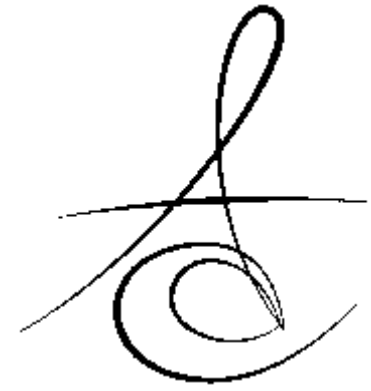

Makale Kodu/Article code: 1032

Makale Gönderilme tarihi: 08.01.2013

Kabul Tarihi; 12.04.2013

\section{DİŞ HEKİMLİĞİNDE FOTODİNAMİK TEDAVİ}

\author{
PHOTODYNAMIC THERAPY IN DENTISTRY
}

\author{
Doç. Dr.Gül TOSUN*
}

\section{ÖZET}

$\mathrm{Bu}$ derlemede, antibiyotik tedavileri sonucu oluşan "direnç" sorununa çözüm olarak gösterilen antimikrobiyal fotodinamik tedavi (FDT)' nin tarihçesi, etki mekanizması, diş hekimliğinde kullanım alanları ve yan etkileri literatür ışığında incelenmiştir.

Anahtar Kelimeler: Fotodinamik Tedavi, Diş hekimliği

Güneş ışığı Eski Mısır, Roma ve Uzak Doğu kültürlerinde, hastalıkların tedavisi amacıyla yüzyıllar boyunca kullanılmıştır. ${ }^{1}$ Yunan medeniyetinde ışı ile tedavi yaygınlaşmış ve "helioterapi" terimi ortaya konulmuştur. $^{2}$

Fototerapiyi bilimsel bir yöntem olarak ilk kez Niels Finsen kullanmıştır. 19. yy'ın sonlarında Finsen kırmızı ışık kullanarak çiçek hastalığını tedavi etmeyi başarmıştır. Güneşten elde ettiği UV ışı̆ı kullanarak lupus vulgaris (deri tüberkülozu)'i tedavi etmeyi başaran Finsen, bu çalışmasıyla Nobel ödülü almıştır. ${ }^{3}$

Rabb, Jesionek ve Von Tappenier 1904 yılında ışı̆ın, duyarlaştırıcı bir ajan ve oksijen ile birlikte kullanımının hastalıklı hücreleri hasara uğrattığını göstererek, bu durumu "fotodinamik tedavi" (FDT) olarak isimlendirmişlerdir. ${ }^{4}$

Alexander Fleming'in 1928 yllında penisilini keşfetmesiyle birlikte antimikrobiyal FDT önemini kaybetmiştir. Antibiyotiklerin kullanıma girmesinin hemen ardından günümüzde de artarak devam etmekte olan "direnç" sorunu alternatif tedavi arayışlarını yeniden gündeme getirmiştir. ${ }^{5}$

\section{ABSTRACT}

In this review, history, action mechanism, usage areas in dentistry, and side effects of antimicrobial photodynamic therapy (PDT), is considered as a solution to "resistance" problem resulting from antibiotic treatments, was investigated in the light of literature.

Key words: Photodynamic therapy, Dentistry

\section{FOTODİNAMİK TEDAVİNİN ETKİ MEKANİZMASI}

FDT; fotosensitizör (FS) bir ajan varlığında, uygun dalga boyunda ve dozunda bir ışık uygulamasıyla reaktif oksijen türleri oluşturularak hedef hücrelerin canlılığının son bulması olarak tanımlanmaktadır. ${ }^{3,5}$ Fotosensitizasyon için, toksik olmayan 3 komponent; fotosensitizör, ışık ve oksijen gereklidir. ${ }^{6}$

Fotosensitizasyon reaksiyonlarının ilk basamağı, foton enerjsinin fotosensitizör tarafından emilmesidir. FS'ler görünür ışığı absorbe ederek elektron taşınımını sağlayan veya ışık enerjisini çevresine aktarabilen ışığa duyarlı ajanlardır. Oksijen varlığında mikroorganizmalar için toksik olan oksidatif reaksiyonlara neden olurlar. ${ }^{6,7}$

Uygun dalga boyundaki ışığı absorbe eden FS düşük enerji seviyesine sahip olan tekil durumundan uyarılmış tekil duruma geçer. Daha sonra FS uyarılmış tekil durumdan ışığın açığa çıkması sonucu tekil duruma dönebilir ya da yüksek enerji seviyesine sahip uyarılmış üçlü durumuna geçer. Uyarılmış üçlü durum yüksek reaktiviteye sahip tekil oksijen ve diğer serbest

\footnotetext{
* Selçuk Üniversitesi, Diş Hekimliği Fakültesi, Pedodonti Anabilim Dalı,
} 
radikalleri oluşturarak hedef dokuda hızlı ve selektif bir yıkıma neden olur. Fotosensitizörün uyarılmış üçlü durumun biyomoleküller ile etkileşiminde iki mekanizma meydana gelmektedir. ${ }^{8-10}$

Tip I reaksiyonda, FS'den doğrudan elektron/ hidrojen transferi, iyonların oluşumu, redoks reaksiyonları veya substrat molekülden elektron/hidrojen ayrılması ile serbest radikaller oluşur. Bu radikallerin oksijen ile hızı bir şekilde tepkimeye girmesi sonucunda süperoksit, hidroksil radikalleri ve hidrojen peroksit gibi reaktif oksijen türleri oluşur. ${ }^{9,10}$

Tip II reaksiyonda, FS uyarılmış üçlü formunun enerjisini moleküler oksijene aktarması sonucu elektronik olarak uyarılmakta ve oksijenin yüksek reaktif formu olarak bilinen tekil oksijen oluşmaktadır. Reaksiyon zinciri sırasında oluşan uyarılmış tekil oksijen, süperoksit, hidroksil ve diğer serbest radikaller; nükleik asitler, enzimler ve hücre zarlarını hedef alarak FDT 'deki doku tahribatını sağlar. Çoğunlukla her iki mekanizma da beraber ilerlerken, FDT'deki doku tahribatından daha çok tip II mekanizma sorumludur. Ancak bilinmesi gereken iki mekanizmanın da oluşturduğu zararın oksijene ve FS'ün konsantrasyonuna bağlı olduğudur. 3,9.10

\section{Fotosensitizör Maddeler}

Fotosensitizör, hedef hücre ile reaksiyona girerek hücreyi ışığa karşı duyarlı hale getiren maddedir. FS'nin kimyasal nitelikleri FDT'nin etkinliğinin belirleyicisi olacağı için, FS'lerden belirli fiziksel, kimyasal ve biyolojik özellikler taşımaları beklenir. ${ }^{3}$ İdeal bir FS, kimyasal anlamda saf olmalı, seçici olarak neoplastik dokuda yoğunlaşmalı, kısa süre içinde hedef dokuda en yüksek konsantrasyonuna ulaşabilmeli ve sağlıklı dokudan kısa sürede uzaklaşabilmelidir. ${ }^{11}$

Mikrobiyal enfeksiyonların tedavisinde kullanılacak fotosensitizör ajanlardan yeterli fotofiziksel (maksimum absorbsiyon dalgaboyu, ışık absorbsiyon miktarı) ve fizikokimyasal (lipofilite, iyonizasyon) özelliklerine ek olarak yüksek miktarda uzun ömürlü üçlü ve sitotoksik tekil form oksijen oluşturması istenmektedir. Aynı zamanda bu ajanlar, enfeksiyon etkeni olan mikrobiyal hücreleri öldürürken, enfeksiyon alanındaki konak dokularda minimal hasara yol açmalı ve tedavi sonrası patojen mikroorganizmaların tekrar çoğalmasını engellemelidir. ${ }^{3}$

Fotosensitizör olarak boyalar, ilaçlar, kozmetik, kimyasal ve çesitli doğal maddelerden oluşan 400'den fazla bileşik bilinmektedir. Tıbbi amaçla kullanılan sensitizörlerin birçoğu aşağıdaki temel yapılara sahiptir. ${ }^{12,14}$

1. Farklı mezo-atomlar içeren trisiklik boyalar: Akridin boyaları, riboflavin, proflavin, metilen mavisi, "toluidine blue $\mathrm{O}^{\prime}$ (TBO), floresein, eozin, eritrozin, roz bengal

2. Makrosiklik tetrapiroller: Porfirin ve türevleri, klorofil, filoeritrin, Fitalosiyaninler

3. Doğal ajanlar: Furanokumarinler (psoralen, ksantoin, bergapten), perilenkinonoidler.

Doğal antimikrobiyal fotosensitizör ajanlar, bitkilerin mikrobiyal veya ökaryotik organizmalara karşı kimyasal savunmada kullandıkları maddelerdir.

\section{FOTODİNAMİK TEDAVİNİN DİŞ HEKİMLİĞİNDE KULLANIM ALANLARI}

\section{Ağız Enfeksiyonlarında Fotodinamik Tedavi}

Geçen yüzyılın başında, ağız içi mikroorganizmaların(MO) kontrol altına alınmasında boya ve ışık kombinasyonu kullanılmış olsa da, antibiyotiklerin kullanımının yaygınlaşması ile antimikrobiyal FDT geri planda kalmıştır. ${ }^{3}$ Son yıllarda metisilin dirençli S.aures, vankomisin dirençli E.faecalis gibi antibiyotiğe dirençli mikroorganizmaların ortaya çıkması, araştırmacıları alternatif tedaviler araştırmaya yönlendirmiştir ve özellikle deri ve ağız boşluğundaki lokalize enfeksiyonlarda alternatif bir tedavi olarak FDT sunulmuştur. ${ }^{15}$

Oral Liken Planus (OLP) oral mukozada oldukça sık olarak rastlanılan özellikle bukkal mukozada görülen kronik bir hastalıktır. Lezyonların spesifik bir tedavisi yoktur. Aktif ve semptomatik OLP'de topikal steroid uygulamaları en sık kullanılan tedavi yöntemidir. Steroid tedavisine alternatif olarak Aghahosseini ve ark. metilen mavisi ile FDT'nin kombine kullanımının inflamatuar hücre artışını azaltarak, OLP'nin tedavisinde etkili olduğunu öne sürmüştür. ${ }^{16,17}$

Kandidiazis, başta Candida albicans olmak üzere, Candida türleri tarafından oluşturulan, ağızda görülen en sık mantar infeksiyonudur. Kandidiazisin oluşmasında risk faktörleri, viral infeksiyonlar, posttransplantasyon ilaçları, yaşa bağlı immune yetmezlikler, demir eksikliği, lenfoma ve lösemi gibi tümörler, sialedenit, antibiyotik kullanımları, radyasyon, ağız kurulukları, otoimmün hastalıklar, protezler ve implantlar, kortikostreoid ve sitotoksik ilaçların kullanımıdır. Oral Kandidiazis'in tedavisinde, topikal antifungal ajanlar kullanılmaktadır. Fakat, bu ajanlar geçici olarak yanıt

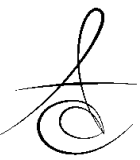


verirler ve nüks sık görülür. ${ }^{18}$ Candida albicans ve albicans dışı Candida türlerinde flukonazol gibi antifungal ajanlara karşı giderek artan oranlarda direnç geliştigi bildirilmektedir. Antifungal direnci özellikle bağışıklık sistemi baskılanmış hastalarda tedavi başarısızığına yol açmaktadır. Antimikrobiyal fotodinamik tedavi oral kandidiyazis ve antifungal dirence bağlı olarak görülen problemlerin tedavisinde değerli bir yöntem olarak görülmektedir. ${ }^{19}$

Herpes simpleks virus (HSV) bir DNA virüsüdür ve insanlar bu virus grupları için doğal kaynaklardır. Herpes virüsler için birçok tedavi ileri sürülmüş olsa da hiçbiri virüsün reaktivasyonunu engelleyememiştir. Herpes Labialis tedavisinde düşük seviyeli lazer tedavisi bir seçenek olarak düşünülmüş, veziküllerin tekrarının sıklığı azalmış ve hastalarda rahatlama sağlamıştır. Lezyonlar hızla iyileşmiş ve herhangi bir akut yan etki görülmemiştir. ${ }^{20}$

Biyofilmin İnaktivasyonunda ve Çürüğün

\section{Sterilizasyonunda FDT}

Ağız boşluğu, hem yumuşak hem katı yüzeyleri birlikte barındırması, yüzeyleri yıkayan tükürük ve diş eti oluk sıvısının varlığı ve dış ortama açık olması özellikleriyle çok kompleks bir yapıdır. Ekolojik olarak çok farklı mikroçevrelerden oluşur; bu nedenle çok çeşitli mikrofloralar içerir. ${ }^{21}$

Ağızda bulunan mikroorganizmaların çoğu, biyofilm olarak adlandırılan bir yüzeye yapışık mikroorganizma topluluklarına aittir. ${ }^{22}$ Diş çürüklerinin ve periodontal hastalıkların önemli patojenik faktörlerinden biri mikrobiyal plak/biyofilmdir. ${ }^{23}$

Diş çürüğü oluşumunun önlenmesi ve kontrol edilmesinde diş üzerinde bulunan patojenik MO'ların ortadan kaldırılması esastır. Streptococcus mutans dental plağın içerisinde bulunan en önemli bakterilerden biridir. ${ }^{24}$ Diş çürüğünde $S$.mutans'ın yanında $S$. sobrinus, Lactobacillus casei and Actinomyces viscosus adlı MO'ların da etkili olduğu yapılan çalışmalarla gösterilmiştir. ${ }^{25}$

Diş çürüğü, diş dokusunun başlangıçtaki mineral kaybından dentin dokusunun organik kaybına kadar ilerleyebilen kronik bir hastalıktır. Diş hekimliğinde plaktaki mikroorganizmaları hedef alan FDT koruyucu yöntem olarak ve çürük kavitesindeki bakterileri elimine ederek noninvaziv bir yöntem olarak kullanılabilir. ${ }^{9}$

Laser ve farklı dalga boylarındaki LED'lerin çeşitli fotosensitizör daylarla kullanımı dental plağın kaldırılmasında alternatif bir tedavi olarak önemli bir rol oynar. ${ }^{24,26}$ Bevialacqua ve ark. FAKT 'nin planktonik kültürde biyofilm oluşumunun önlenmesinde ve mikroorganizmaların öldürülmesinde etkili olduğunu göstermişlerdir. ${ }^{24}$ İn vitro olarak yapılan bir çalışmada Streptococcus mutans, S. sobrinus ve $S$. Sanguinis içeren biyofilmde fotosensitizasyondan sonra bakteri sayısında \%95-99 azalma görüldüğü bildirilmiştir. ${ }^{27}$

Çürük lezyonunda bulunan bakteri, fotosensitizasyon ile in vivo olarak ortadan kaldırılabilirse; restorasyondan önce dentin çürüğündeki mikroorganizmaları elimine etmek ve enfekte bölgeden daha az madde kaldırılarak güçlü bir diş yapısı sağlamak için yararlı bir yaklaşım olacaktır. FDT' nin çürük tedavisindeki etkinliğini kanıtlayabilmek için daha fazla çalışma yapılması gerekmektedir.

\section{Periodontoloji Alanında FDT}

Periodontal hastalıklar, oral kavite içerisinde FDT'nin uygulanabileceği temel alanlardan birisidir. Enfeksiyonun multifaktöriyel olması ve birçok farklı bakteri tarafından oluşturulması, bakterilerin enfeksiyon bölgesindeki lokalizasyonu ve yöntemin kolay uygulanabilir olması FDT'nin periodontal hastalıklarda kullanılabilme gerekçeleri arasındadır. ${ }^{9}$ Bu tedavide fotosensitizör, periodontal cep içerisine uygulandıktan sonra, ince gingival doku üzerinden veya fiber optikler aracılığıyla doğrudan periodontal cep içerisinden aydınlatma sağlanabilir. ${ }^{28,29}$

Kömerik ve ark. ${ }^{28}$ birleşik periodontal dokuları zarar görmemiş, periodontitisle ilişkili kemik yıkımı olmayan hayvan modellerinde P.gingivalis'in TBO aracılı FDT tarafından öldürülüp öldürülmediği araştırılmıştır. Ratların maksillar molarların gingival yarıklarına P.gingivalis ekilerek TBO varlığında diyot lazer $(630 \mathrm{~nm})$ ışığa maruz bırakıldığı tedavi sonucunda, yaşayan bakteri kalmadığı ve fotosensitizasyon işleminin kemik kaybındaki azalmayı belirgin düzeyde engellediği görülmüştür.

Chan ve Lai ${ }^{5}$ dalga boyu veya doza bağlı olarak Actinobacillus actinomycetemcomitans, Fusobacterium nucleatum, Porphyromomas Gingivalis, Prevotella intermedia ve Streptococcus sanguis gibi periodontal patojenlerin sitotoksik bakteriyal etkisini açıklayan bir çalışma sunmuşlardır. $\mathrm{Bu}$ patojenler uygun fotosensitizör olarak Metilen mavisi varlığında veya yokluğunda HeNe lazerine (632.8 nm, $30 \mathrm{~mW}), 100$ $\mathrm{mW}$ diyode lazer $(665 \mathrm{~nm}), 100 \mathrm{~mW}$ diyot laser (830 $\mathrm{nm})^{\prime} \mathrm{e}$ maruz bırakılmışlardır. En etkili kombinasyon

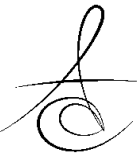


test edilmiş, çeşitli türlere karşı MM'si ile 100 mW altında 665 nm'lik diyot lazer olarak bulunmuştur.

Fotodinamik tedavisinin etkisinin incelendiği çalışmalarda örneklenen toplumun karakteristiği (cinsiyet, yaş, ırk, genetik, sosyo-ekonomik yapı) ve periodontitis çeşitlerinde önemli farklılıklar bulunmakla birlikte çalışmalar sonucunda FDT'nin tek başına etkili olduğu kanıtlanamamıştır. ${ }^{30}$ Fotodinamik tedavi, cerrahi olmayan tedaviyle birlikte kullanıldığında ataçman seviyesinde tutarlı bir artış ve sondlama derinliğinde azalma tespit edildiği bildirilmiştir. ${ }^{11,31,32}$

\section{Endodonti Alanında FDT}

Endodontik tedavi kök kanal sistemi içindeki bakterilerin mekanik temizleme ve kimyasal yıkama protokolü ile ortadan kaldırılması için yapılan girişimlerdir. Kök kanal sisteminin kök dallanmaları, lateral kanallar ve isthmuslarla ortaya çıkan anatomik karmaşıklık bakterilerin tamamen ortadan kaldırılmasını imkansız hale getirir.

Günümüzün en gelişmiş yöntemleriyle bile kök kanal sisteminin dezenfeksiyonu tam anlamıyla sağlanamamaktadır. ${ }^{33}$ Enfekte bir dişin kanallarındaki bakterilerin kaldırılabilmesi için, çoğunlukla inatçı enfeksiyonlarda kanal tedavisinin yenilenmesi veya periradiküler cerrahi gerekmektedir. Bu nedenle, endodontik tedavinin başarı oranını arttırmak için geleneksel endodontik antimikrobiyal işlemlere katkıda bulunacak yeni yöntemler geliştirilmiştir.

Her ne kadar FDT kanser tedavileri için geliştirilmiş bir yöntem olsa da, yapılan çalışmalar bu tedavi yönteminin oral bakterilere karşı da etkin olduğunu göstermiştir. ${ }^{34}$ Endodontik tedavinin en önemli basamaklarından biri olan kök kanalı içerisindeki bakterilerin ortadan kaldırılmasıdır. Günümüzde, FDT kök kanal sistemindeki mikroorganizmaların ortadan kaldırılması için tedaviye yardımc bir yöntem olarak gösterilmektedir. ${ }^{35}$

MO'lar içinde en inatçı ve tedavinin başarısını tehliye atan bakterilerin başında E.faecalis gelmektedir. Çekilmiş tek köklü insan dişleri E.faecalis ile kontamine edildikten sonra FS olarak azulen pastası kök kanalları içerisinde 5 dak. süreyle bekletilmiş ardından da kırmızı ışıkla (685 nm) aydınlatma yapılmıştır. FS veya lazerin tek başına kullanımında herhangi bir bakteriyal etki oluşturmadığı gözlenmiştir. Kimyasal solüsyon kullanımı canlı bakterilerin $\% 93.25$ 'ini, lazer fotosensitizasyon ile bakterilerin \%99.2 'sini azalttığı bildirilmiştir. ${ }^{36}$
Sonuç olarak literatürde FDT'nin sağlıklı hücrelere yakın patojen mikro-organizmalara karşı güvenilir bir şekilde kullanılabileceği bildirilmiştir. FDT'nin sitotoksitesi geleneksel antimikrobiyal yöntemlere göre oldukça düşüktür. Sitotoksitenin az olması kanal preparasyonu sırasında periradiküler bölgeye itilen kimyasalların enflamatuar bir reaksiyon oluşturmaması açısından tercih edilebilir. Yapılan birçok çalışma sonucunda FDT geleneksel endodontik tedaviye yardımcı bir yöntem olarak kullanılabileceğini göstermiştir. ${ }^{36,37}$

\section{Ağız, Diş ve Çene Cerrahisi Alanında FDT}

Oral kanserler dünyada birçok ülkede ciddi bir problemdir. Önemi ve ciddiyeti sadece yüksek oranda mortaliteye sahip olmasında değil aynı zamanda fonksiyonel ve psikolojik boyutları olmasındandır.

Oral kanserler, dünya çapında en sık rastlanılan kanserlerden ve en çok görülen 10 ölüm nedenlerinden birisidir. $^{38}$ Yüksek mortalite riski yanı sıra meydana getirdiği fonksiyonel ve psikolojik sorunlar nedeniyle oral kanserler dünyada birçok ülkede ciddi bir problem olarak görülmektedir. Cerrahi işlem veya radyasyon uygulaması oral kanser tedavisi için iyileştirici amaçla kullanılır. Kemoterapi ise radyasyon ve cerrahi tedavi seçeneklerine ek olarak kullanılmaktadır. Cerrahi ve radyasyonun birlikte uygulanması ise genellikle daha ilerlemiş olgularda tercih edilir. İleri vakalarda kemoterapi, cerrahi veya radyoterapi ile ya da üçü bir arada kombine kullanılır.

Geleneksel tedaviler çene ağrısı, ağız yaraları, tükürük bezlerinin disfonksiyonu, çiğnemede güçlük, konuşamama ve şişlik gibi durumlar ortaya çıkabilmektedir. ${ }^{39}$ Oral kavite kanserleri büyük çoğunlukla prekanseröz lezyonları izleyerek ortaya çıkar. Eritroplaki ve displastik lökoplaki pre-kanseröz lezyonların en yaygın belirtileridir ve oral skuamöz hücreli karsinomu (SHK)'nun yarısından fazlası lökoplaki belirtisiyle görülmektedir. ${ }^{40}$ Fotodinamik esaslı tedavi; premalign, birincil, tekrarlayan ve metastatik lezyonları içeren farklı baş ve boyun kanserlerinde alternatif bir tedavi yöntemi olabilir.

FDT'nin geleneksel tedaviye göre avantajları; daha az invaziv olması ve sağlıklı dokuları koruyarak seçici tümör yıkımını sağlamasıdır. Bazı FS'ler tümörlerde konsantre olması istenilen bir özelliktir. ${ }^{41}$ FDT'nin bu özellikleri fonksiyon kaybına neden olacak fazla doku kaybını azalttığı için baş ve boyun skuamöz hücreli karsinoma için önemlidir. Sonuç olarak, FDT

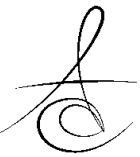


geleneksel tedaviye ek olarak uygulanabilir.

\section{FOTODİNAMİK TEDAVİNİN YAN ETKİLERİ}

FS kullanımından sonraki en büyük yan etki foto hassasiyettir. Sensizitörün sistemik uygulanması deride fotosensizitörün uyarımı ile rezidüel deri fotohassasiyet dönemiyle sonuçlanır. Bazı FS 'ler gün ışığıyla aktive olur. Birinci veya ikinci derece yanıklara neden olur. Bundan dolayı, ilaç elimine edilene kadar birkaç saat veya haftaya değişen bir süre doğrudan güneş ışığı alınımından sakınılmalı, güneş ışığına maruz kalınacağı durumlarda deri ve gözde korucu önlem alınması sağlanmalıdır. ${ }^{12}$

FDT'nin sistemik yan etkileri baş ağrısı, bulantı, kusma, karın ağrısı, diare, ağız kuruluğu, nefes darlığı, baş dönmesi, hiperestezi ve parestezi olup tedavi uygulamasını durdurmayı gerektirmezler. Genelde FDT, işlem sırasında ağrılı bir tedavi olmamasına karşın ilerleyen saatlerde çok sayıda hastada şiddetli ağrı şikayetine rastlanır. Bu nedenle ağrı kesicilerin lazer tedavisinden hemen önce veya sonra verilmesi tavsiye edilmektedir. ${ }^{12}$ Nadir olarak da, kullanılan FS ve/veya hastaya bağlı olarak allerjik reaksiyonlar, akciğer parametrelerinin değiştirilmesi durumları gözlenebilmektedir. $^{42,43}$

\section{SONUÇ}

Fotodinamik tedavinin, yapılan birçok araştırma sonucu, diş hekimliği alanında kullanılabileceği gösterilmiştir. Düşük toksisitesi ve hücre seçici özelliğinin yanı sıra FTD' nin antibiyotik tedavileri sonucu oluşan "direnç" sorununa bir çözüm olarak düşünülebileceği ileri sürülmektedir. Bu konuda yapılacak çalışmalarda FS'nin hasta doku üzerindeki seçiciliğinin arttırılması ve fotohassasiyetin azaltılması üzerine yoğunlaşılmalıdır.

\section{KAYNAKLAR}

1. Moan J, Peng Q. An outline of the hundred-year history of PDT. Anticancer Res 2003; 23: 3591600.

2. Daniell MD, Hill J.S. A history of photodynamic therapy. Aust N Z J Surg 1991. 61: 340-8.

3. Kutlubay Z, Pehlivan Ö, Engin B. Fotodinamik Tedavi. Dermatoz 2011; 2: 391-404.

4. Meisel $P$, Kocher $T$. Photodynamic therapy for periodontal diseases: state of the art. J Photochem Photobiol B 2005; 79: 159-70.

5. Finsen NR. Remarks on the red-lıght treatment of small-POX: Is the Treatment of Small-pox Patients in Broad Daylight Warrantable? Br Med J 1903; 1: 1297-8.

6. Wainwright, M. and K.B. Crossley, Methylene Blue-a therapeutic dye for all seasons? J Chemother 2002; 14: 431-43.

7. Hayata $Y$, et al. Fiberoptic bronchoscopic laser photoradiation for tumor localization in lung cancer. Chest 1982; 82: 10-4.

8. Waidelich $\mathrm{R}$, et al. Whole bladder photodynamic therapy with 5-aminolevulinic acid using a white light source. Urology 2003; 61: 332-7.

9. Foote CS. Definition of type I and type II photosensitized oxidation. Photochem Photobiol 1991; 54: 659.

10. Brault, D., et al., Chlorin-type photosensitizers photochemically derived from vinyl porphyrins. Photochem Photobiol, 2001. 73: 331-8.

11. Reddi E, et al. Photophysical properties and antibacterial activity of meso-substituted cationic porphyrins. Photochem Photobiol 2002; 75: 46270.

12. Luksiene Z. Photodynamic therapy: mechanism of action and ways to improve the efficiency of treatment. Medicina (Kaunas) 2003; 39: 1137-50.

13. Wainwright M. Photodynamic antimicrobial chemotherapy (PACT). J Antimicrob Chemother 1998; 42: 13-28.

14. Wainwright $M$, Byrne $M N$, Gattrell MA. Phenothiazinium-based photobactericidal materials. J Photochem Photobiol B 2006; 84: 227-30.

15. Wainwright $M$. The use of dyes in modern medicine. Biotech Histochem 2003; 78: 147-55.

16. Hamblin MR, Hasan T. Photodynamic therapy: a new antimicrobial approach to infectious disease? Photochem Photobiol Sci 2004; . 3: 436-50.

17. Aghahosseini F, et al. Treatment of oral lichen planus with photodynamic therapy mediated methylene blue: a case report. Med Oral Patol Oral Cir Bucal 2006; 11: E126-9.

18. Aghahosseini, F., et al., Methylene blue-mediated photodynamic therapy: a possible alternative treatment for oral lichen planus. Lasers Surg Med 2006; 38: 33-8.

19. Ezirganlı, S., et al., Oral Liken Planus: Retrospektif Bir Çalışma. J Dent Fac Ataturk Uni 2010; 20: 1004. 
20. Gursoy $\mathrm{H}$, et al.Photodynamic therapy in dentistry: a literature review. Clin Oral Investig 2013; 17: 1113-25.

21. Maisch T. Anti-microbial photodynamic therapy: useful in the future? Lasers Med Sci 2007; 22: 8391.

22. Marotti J, et al. Photodynamic therapy can be effective as a treatment for herpes simplex labialis. Photomed Laser Surg 2009; 27: 357-63.

23. Aas JA, et al. Defining the normal bacterial flora of the oral cavity. J Clin Microbiol 2005; 43: 5721-32.

24. Avila M, Ojcius DM, Yilmaz O. The oral microbiota: living with a permanent guest. DNA Cell Biol 2009; 28: 405-11.

25. Costerton, J.W., Introduction to biofilm. Int J Antimicrob Agents 1999; 11: 217-21; discussion 237-9.

26. Bevilacqua IM, et al. The impact of photodynamic therapy on the viability of Streptococcus mutans in a planktonic culture. Photomed Laser Surg 2007; 25: $513-8$

27. Joyston-Bechal S, Kidd EA. The effect of three commercially available saliva substitutes on enamel in vitro. Br Dent J 1987; 163: 187-90.

28. Wilson M. Bactericidal effect of laser light and its potential use in the treatment of plaque-related diseases. Int Dent J 1994; 44: 181-9.

29. Costerton JW, Stewart PS, Greenberg EP. Bacterial biofilms: a common cause of persistent infections. Science 1999; 284: 1318-22.

30. Komerik $\mathrm{N}$, et al. In vivo killing of Porphyromonas gingivalis by toluidine blue-mediated photosensitization in an animal model. Antimicrob Agents Chemother 2003; 47: 932-40.

31. Jori, G., et al., Photodynamic therapy in the treatment of microbial infections: basic principles and perspective applications. Lasers Surg Med 2006; 38: 468-81.

32. Azarpazhooh A, et al. The effect of photodynamic therapy for periodontitis: a systematic review and meta-analysis. J Periodontol 2010; 81: 4-14.

33. Hayek RR, et al. Comparative study between the effects of photodynamic therapy and conventional therapy on microbial reduction in ligature-induced peri-implantitis in dogs. J Periodontol 2005; 76: 1275-81.

34. Demidova TN, Hamblin MR. Photodynamic therapy targeted to pathogens. Int J Immunopathol
Pharmacol 2004; 17: 245-54.

35. Verma DK, Nair PN, Luder HU. Quantitative histological and ultrastructural features of opercula of normally erupting human teeth. Microsc Res Tech 2005; 67: 279-85.

36. Dougherty TJ, et al. Photodynamic therapy. J Natl Cancer Inst, 1998; 90: 889-905.

37. Wilson M, Dobson J, Harvey W. Sensitization of oral bacteria to killing by low-power laser radiation. Curr Microbiol 1992; 25: 77-81.

38. Garcez AS, et al. Antimicrobial effects of photodynamic therapy on patients with necrotic pulps and periapical lesion. J Endod 2008; 34: 13842.

39. Fimple JL, et al. Photodynamic treatment of endodontic polymicrobial infection in vitro. J Endod 2008; 34: 728-34.

40. Massano J, et al. Oral squamous cell carcinoma: review of prognostic and predictive factors. Oral Surg Oral Med Oral Pathol Oral Radiol Endod 2006; 102: 67-76.

41. Silverman SJ. Oral cancer: complications of therapy. Oral Surg Oral Med Oral Pathol Oral Radiol Endod 1999; 88: 122-6.

42. van der Waal I. Axell T. Oral leukoplakia: a proposal for uniform reporting. Oral Oncol 2002; 38: 521-6.

43. Nseyo UO, et al. Photodynamic therapy (PDT) in the treatment of patients with resistant superficial bladder cancer: a long-term experience. J Clin Laser Med Surg 1998; 16: 61-8.

44. Biel MA. Photodynamic therapy in head and neck cancer. Curr Oncol Rep 2002; 4: 87-96.

45. Van Den Berg $H E$, Ballini JP. Principle of photodynamic therapy. In Photodynamic therapy of ocular diseases. Editörs: Gragoudas ES, Miller JW, Zografos L. Lippincott Williams \& Wilkins, Philadelphia 2004.
Yazışma Adresi
Dr. Halenur ONAT
Konya Üniversitesi
Diş Hekimliği Fakültesi
Pedodonti Anabilim Dalı
KONYA
Telefon: 5057523376
E-mail: onat_2012@windowslive.com 